\title{
Perspectivas globais sobre organizações de trabalhadores e do trabalho
}

Global Perspectives on Workers' and Labour Organizations

ATZENI, Maurizio; NESS, Immanuel (Eds). Global Perspectives on Workers' and Labour Organizations. Singapore: Springer, 2018.

O livro editado pelos pesquisadores Maurizio Atzeni (Argentina) e Immanuel Ness (EUA) oferece um panorama sobre as alterações mais recentes no mundo do trabalho, enfocando o aspecto da organização dos trabalhadores. A nivel global e de forma geral, o capitalismo se reconfigurou em várias dimensões sistêmicas e trouxe maior complexidade e precariedade às relações do trabalho. E sob o signo da precariedade, deterioraram-se também as tradicionais formas de organização e luta dos trabalhadores. Com diversas pesquisas e abordagens, o livro representa um esforço coletivo para responder algumas questões que surgem daí: quais subjetividades/identidades coletivas emergem nesse novo contexto social, político e produtivo? As organizações trabalhistas estão sendo ou tendem a ser revitalizadas? De que maneira?

Interessante notar as mutações epistemológicas e metodológicas advindas do estudo desse novo objeto, tomado aqui, de forma comparativa. Os editores, assim como os autores dos capítulos, ressaltam a importância de articular as esferas de produção e reprodução social e suas respectivas formas de resistência. O enfoque clássico nos sindicatos oficiais já é insuficiente para apreender a luta de trabalhadores que, por exemplo, encontram-se na fronteira entre o formal e o informal, e/ou entre o produtivo e o improdutivo. E por isso, o ponto de vista e de partida dos

\footnotetext{
1 Doutorando em Ciência Política (UnB). E-mail: alexmpimenta1@gmail.com Cidade: Brasilia.
} 
estudos de caso do livro é o trabalho/trabalhador precário e sua complexa relação com outros agentes e espaços sociais.

O livro é dividido em duas partes. Reprodução da vida nos espaços urbanos e Produção do valor na indústria. O primeiro contendo cinco capítulos; já o segundo, quatro capítulos.

O capítulo 1, de Ian Thomas MacDonald, Repensando o sindicalismo nos espaços de trabalho precário, traz uma interessante reflexão sobre os limites e distanciamentos do sindicalismo diante de uma imensa massa de trabalhadores precarizados de maneira multi-dimensional. Como solução, e tomando a América do Norte como cenário, aponta para a necessidade de se pensar a luta trabalhista para além das estratégias sindicais mais clássicas, que em muitos casos representam apenas setores em declínio no mundo do trabalho e/ou por demais corporativos e burocratizados. Um movimento mais politizado, urbano, descentralizado das empresas/categorias e articulado aos chamados novos movimentos sociais aparenta ser um modelo mais eficiente de combate à precariedade.

O segundo capítulo, de Joyce Jiang, se chama Organizando trabalhadores imigrantes através de "comunidades de enfrentamento": uma análise da jornada dos trabalhadores domésticos migrantes de um trabalho individual de amor para um trabalho coletivo com direitos. O texto trata de uma etnografia feita em Londres entre os anos de 2009 e 2012, mais especificamente na associação "Justice For Domestic Work" (J4DW). Como o título indica, Jiang estuda um caso que intersecciona múltiplos aspectos de suma importância na precariedade do trabalho contemporâneo. Migração, economia do cuidado (e por isso, raça e gênero), formas de associativismos de estilo mais comunitário, são temas que a autora analisa e articula, indicando a existência e a possibilidade de resistência coletiva e solidariedade classista inclusive em categorias dispersas e com poucos recursos políticos e de representação.

Em seguida, P. O'Hare é o autor de Acionando clandestinidade $e$ visibilidade entre os catadores de materiais recicláveis do Uruguai. Sua pesquisa é focada nas distintas dinâmicas de resistência e luta dos trabalhadores de coleta de materiais recicláveis na cidade de Montevidéu. 
Enquanto o sindicato oficial é caracterizado por ações regidas por uma lógica do espetáculo e da visibilidade, boa parte da "base" dos trabalhadores se encontra em situação informal nos aterros sanitários e necessita recorrer a estratégias cotidianas mais clandestinas, regionais e sigilosas. Essas estratégias, busca ressaltar o autor, são de complexa relação com a dimensão de visibilidade e não podem ser reduzidas a um individualismo pré-politico.

No capítulo quatro, intitulado "Fábricas de suor" locais na economia global: dinâmicas de acumulação e a produção de um exército industrial reserva, Jerónimo Montero Bressán se debruça sobre o retorno/emergência do trabalho forçado existente nas "sweatshops" locais e sua relevância para o capitalismo atual, sobretudo na indústria da moda. O trabalho forçado e ultraprecarizado age, nesse contexto, também como uma espécie de exército industrial de reserva a minar os "privilégios" de trabalhadores formais. Analisando o caso argentino, o autor nota as dificuldades de combate a esse tipo de trabalho, alvo de discriminação e afastamento por parte da militância trabalhista - esta sendo substituída por movimentos onguistas sem perspectiva de organização e resistência mais ampla.

Politica trabalhista e trabalhadores do varejo sul-africanos: coletividades duradouras diante da precariedade, de Bridget Kenny, fecha a primeira parte do livro, reforçando a guinada epistemológica do livro. A autora toma a categoria varejista da África do Sul pós-apartheid como objeto privilegiado para mapear subjetividades e ações trabalhistas a partir de baixo, do "concreto". Ou seja, sem dar primazia à esfera institucional, às alianças políticas e à estrutura sindical oficial. Vemos, novamente, como a esfera menos visivel da luta dos trabalhadores consegue construir identidades e instrumentos coletivos com ou sem os sindicatos.

Jenny Chan abre a segunda parte do livro com A resistência coletiva dos operários chineses. A China, após anos de abertura para o mundo capitalista, possui hoje uma enorme relevância na produção global. E seus trabalhadores vivem a paradoxal situação de estar sob um Estado que se diz socialista e ao mesmo tempo encontrar graves barreiras para sua organização e luta. No entanto, diz o autor, uma fase de forte agitação 
trabalhista é possivel se enxergar no país, cujo impacto internacional pode se tornar considerável.

O capítulo 7, “Nós lutamos contra o sindicato!": Uma etnografia das relações de trabalho na indústria automobilistica no México, é escrito por Paolo Marinaro. O autor realizou uma etnografia por três anos nesta que é uma das categorias mais emblemáticas dos estudos sindicais. Verificou-se que a luta desses operários mexicanos contra suas péssimas condições de trabalho ocorrem em grande medida ao largo e contra os sindicatos, que se adaptaram às demandas empresariais. Repertórios mais radicais, como greves selvagens, mobilização clandestina, além da solidariedade internacionalista, são privilegiados pelos ativistas nesse contexto.

O oitavo capítulo, de Kadambari Chheda e Anuradha Patnaik, chama-se Organizando trabalhadoras informais na Índia: experiências a partir da construção civil de Mumbai. Nesse país emergente cujo setor informal é dominante e o patriarcado muito forte, as experiências de operárias construindo sindicatos liderados, administrados e voltados para mulheres ('all-women' unions) se mostram de extrema relevância. Tais sindicatos articulam, de forma ainda muito seminal, demandas das esferas da produção e da reprodução social nas quais o trabalho feminino está submetido.

Por fim, o livro fecha com Jamie Woodcock e a introdução da discussão tecnológica. Trabalho digital e a organização dos trabalhadores se questiona qual trabalho é esse e como este tem afetado práticas de resistências e alternativas organizacionais. Dialogando com a literatura do marxismo autonomista, o autor busca captar nas alterações globais do capitalismo e da divisão internacional do trabalho as pedras angulares para se compreender a composição de classe contemporânea. A luta dos trabalhadores digitais demonstra ainda estar em seus primórdios, mas desde já se enreda em uma dimensão cada vez mais estratégica da luta de classes e da disputa sociopolítica da tecnologia.

Com Perspectivas globais sobre organizações de trabalhadores e do trabalho, Atzeni e Ness nos oferece um frutífero caleidoscópio do mundo do trabalho contemporâneo. O leitor brasileiro certamente se reconhecerá nas 
inúmeras semelhanças, seja de condições de trabalho de certos ramos de produção, seja na situação dramática na qual se encerra o sindicalismo. $O$ cenário internacional, de fato, fala de nós. Os achados e pistas das competentes pesquisas do livro são vários e valiosos para quem se arrisca a estudar a atual precariedade do trabalho e suas resistências. Destacamos: o trabalho enquanto categoria analitica ainda relevante para as ciências sociais; o sindicalismo oficial, com sua forte institucionalização e acomodação política, como uma dimensão limitada para a análise conflito entre o capital-trabalho; a necessidade de se articular as esferas da produção e da reprodução social, assim como demais identidades e coletividades não-classistas à mobilização trabalhista. Aos que estão imersos politicamente nessas resistências, renovar o movimento sindical demasiadamente fordista surge como um imperativo, urgente. Renovar ou, em muitos aspectos, apenas retomar práticas e ideologias que já se encontravam no início do movimento operário, como o mutualismo.

Entretanto, é importante ressaltar, a predominância de pesquisas e dados qualitativos do livro necessita ser dosada com abordagens mais quantitativos e sistemáticos do objeto em questão. Só assim se dará um passo a mais: de uma coletânea de perspectivas para, quiçá, construções teóricas mais robustas que nos indiquem com mais objetividade como operam hoje os complexos e globais conflitos capital-trabalho. 